\title{
PRELIMINARY PHYTOCHEMICAL SCREENING AND IN VITRO ANTIOXIDANT ACTIVITY OF THE METHANOLIC EXTRACT OF LINDERNIA RUELLIOIDES (COLSM.) PENNELL
}

\author{
IMTILEMLA A*, VICKY BAREH, SAMIA BEGAM BARBHUIYA, LALZIKPUII SAILO
}

Regional Institute of Paramedical and Nursing Sciences, Department of pharmacy, Zemabawk, Aizawl, Mizoram. Email: imtihongz@gmail.com

Received: 05 June 2020, Revised and Accepted: 06 July 2020

\section{ABSTRACT}

Objective: The objective of the study was collection of plant materials, Extraction of phytoconstituents using a different solvent, to carry out preliminary phytochemical screening of different extracted solvent, to perform fluorescence analysis, to estimate the proximate composition of the leaves Lindernia ruellioides (Colsm.) Pennell, and to determine the presence of in vitro anti-oxidant of the methanolic extract of the plant.

Method: Preliminary phytochemical screening of the methanolic extract of Lindernia ruellioides (Colsm.) Pennell, estimation of proximate composition of the leaves, fluorescence analysis, total phenolic content, total flavonoids content, and in vitro antioxidant activity of the methanol extract (DPPH scavenging activity, reducing power assay, and nitric oxide scavenging activity).

Results: The result of phytochemical screening of methanolic extract of Lindernia ruellioides (Colsm.) Pennell contents the presence of amino acid, flavonoids, tannins, steroids, and triterpenoids. The moisture content and Ash value were found to be appropriate and the in vitro antioxidant activity of the methanolic extract showed potential antioxidant activity in terms of DPPH scavenging activity, reducing power assay, and nitric oxide scavenging activity.

Conclusion: The work presented here suggests that the methanolic extract of Lindernia ruellioides (Colsm.) Pennell possesses potential antioxidant activity.

Keywords: Lindernia ruellioides, phytochemical screening, DPPH, reducing power, Nitric oxide scavenging activity.

(C) 2020 The Authors. Published by Innovare Academic Sciences Pvt Ltd. This is an open access article under the CC BY license (http://creativecommons. org/licenses/by/4. 0/) DOI: http://dx.doi.org/10.22159/ajpcr.2020.v13i9.38498

\section{INTRODUCTION}

Lindernia ruellioides (Colsm.) Pennell is usually found in the southern part of China. The whole part of the plant can be used medicinally for treating detoxification, injuries, menoxenia, dysmenorrhea, and snakes' and dog's bites [1]. Lindernia ruellioides (Colsm.) Pennell belongs to the family Scrophulariaceae; it is a trailing herb with purple flowers. Medicinally, the leaves are useful in the treatment of wounds, bruises, boils, jaundice, snakebite, dysentery, and urinary troubles. The herb is applied externally for worms in the skin (carter). The whole plant is used as a poultice for cramps, rheumatism, sciatica, wounds, and internally for eye problems [2].

Medicinal plants contain a high amount of anti-oxidant. Anti-oxidant plays an important role in protecting and safeguarding health problem especially in the disease such as cancer. Free radicals are generated by an exogenous and endogenous metabolic in the body causing oxidizing which leads to damage or death of cells and tissue [3]. Herbal plants are traditionally used as medicine and it is considered to be harmless which is consumed or taken by many people without any prescription [4]. The present study is to evaluate phytochemical screening and in vitro antioxidant of methanol extract of Lindernia ruellioides (Colsm.) Pennell.

\section{METHODS}

\section{Collection and authentication of the plant}

The fresh leaves of Lindernia ruellioides (Colsm.) Pennell was collected during the flowering season in June from Khawbung, Aizawl, and Mizoram. Herbarium sheet was prepared and authenticated by the Botanical Survey of India, Eastern Regional Centre, Shillong.

\section{Preparation of plant extract}

The plants were washed and dried under shade until it becomes dry. The dried leaves were crushed into powdered form and were extracted with the help of the Soxhlet apparatus and treated with different solvents; first with petroleum ether followed by chloroform and then finally with methanol until the solvent in the siphon becomes colorless. The solvent recovery was done using a rotary evaporator [5]

\section{Preliminary phytochemical screening}

The crude extract of Lindernia ruellioides (Colsm.) Pennell was screened with a different test such as Alkaloids (Mayer's test, Dragendorff's test, Wagner's test, and Hager's test), amino acid test (ninhydrin test, xanthoprotein test, and biuret test), flavonoids test (Shinoda test, and lead acetate test), tannins test ( ferric chloride test, and lead acetate test), steroids and triterpenoids test (Liebermann-Burchard test, and Salkowski test), and carbohydrates test (Molisch test, Benedict's test, Fehling's test, and Iodine test) [5-7].

\section{Test for alkaloids}

Dragendorff's test

Extract was treated with Dragendorff's reagent (potassium mercuric iodide solution). If an orange-brown precipitate is formed, it indicates the presence of alkaloids.

Mayer's test

Extract was treated with Mayer's reagent (potassium mercuric iodide solution). If a cream-colored precipitate is formed, it indicates the presence of alkaloids.

\section{Wagner's test}

Extract was treated with Wagner's reagent (iodine potassium solutions). If a reddish-brown precipitate is formed, then it indicates the presence of alkaloids 
Hager's test

Extract was treated with Hager's reagent (saturated picric acid solution). If a yellow colored precipitate is formed, it indicates the presence of alkaloids.

\section{Test for carbohydrates}

Molisch test

Extract was treated with Molisch reagent ( $\alpha$-naphthol in 95\% ethanol) and few drops of sulfuric acid were added through the slide of the test tube. If a violet ring appears at the junction, it indicates the presence of carbohydrates.

\section{Benedict's test}

Extract was treated with Benedict's reagent (copper sulfate + sodium citrate + sodium carbonate in water) and heated for 10 min. Redcolored precipitate indicates the presence of sugars.

\section{Fehling's test}

Extract was dissolved in $1 \mathrm{ml}$ of distilled water and filter. One milliliter of Fehling's solution A and B was added to the filtrate and heat in a water bath for few minutes. The formation of a brick-red precipitate indicates the presence of reducing sugar.

Iodine test

Extract was treated with $2 \mathrm{ml}$ of iodine solution. A dark purple or black coloration indicates the presence of carbohydrates.

\section{Test for amino acids}

Millon's test

Extract was treated with Millon's reagent (mercuric nitrate in nitric acid). Red color indicates the presence of proteins.

\section{Ninhydrin test}

Extract was treated with ninhydrin reagent and ammonia and heated. The violet color indicates the presence of proteins.

\section{Xanthoprotein test}

Few drops of nitric acid were added by the sides of the test tube very gently to $1 \mathrm{ml}$ of extract. The formation of yellow color indicates the presence of protein in the sample.

\section{Biuret test}

Extract was treated with sodium hydroxide. Copper sulfate solution was added dropwise. If a violet color is formed, then it indicates the presence of proteins.

\section{Test for steroids and triterpenoids \\ Salkowski test}

To the solution of extract, $2 \mathrm{ml}$ of chloroform and few drops of sulfuric acid were added, boiled, and the moisture was shaken and allowed to stand for some time. Red color indicates the presence of steroids and triterpenoids.

\section{Test for phenols and tannins}

Ferric chloride test

Extract was treated with $1 \mathrm{ml}$ of $5 \%$ ferric chloride solution. Bluish or black color indicates the presence of tannins.

\section{Lead acetate test}

Extract was treated with $1 \mathrm{ml}$ of $10 \%$ lead acetate solution in water. Yellow color precipitate indicates the presence of phenols.

\section{Test for flavonoids}

Shinoda test

Extract was treated with few magnesium turnings and concentrated hydrochloric acid was added dropwise. Formation of pink scarlet, crimson red, or occasionally green to blue color indicates the presence of flavonoids.

\section{Lead acetate test}

Few milliliters of extract solution were treated with $1 \mathrm{ml}$ of $10 \%$ lead acetate solution in water. If a yellow color precipitate is formed, it indicates the presence of Flavonoids.

\section{Proximate composition}

Estimation of moisture content

Approximately $5 \mathrm{~g}$ of the crude drug was weight in a glass stopper shallow weighing bottle and kept in an oven at $105^{\circ} \mathrm{C}$ for $5 \mathrm{~h}$, after which it was kept to cool at room temperature in a desiccator. Then, the weight of the bottle and the sample were taken. The loss in weight is considered as a measure of moisture content in the sample [8].

Moisture $\%=$ (weight of the original sample-weight of the dried sample) $\times 100$ /weight of the original sample.

\section{Estimation of ash content}

Approximately $2 \mathrm{~g}$ of the powdered crude drug was weight in crucible silicon and was heated in a muffle furnace at a temperature of $500^{\circ} \mathrm{C}$ for 4-5 h. The crude drugs were cooled, and weighed and were heated again in a muffle furnace for another half an hour. This was repeated until the weight of the crucible and the crude drugs become constant (ash became white or grayish white) [9].

Ash content $(\%)=($ weight of the Ash/weight of the sample $) \times 100$.

\section{Fluorescence analysis}

Crude drug shows its own characteristics properties when exposed to ultraviolet radiation and is dependent on its chemical constituents. This analysis is useful to identify adulterants during crude drug evaluation. One gram of crude drug was taken in a watch glass and was treated with different reagents and observed under the TLC chamber for the presence of their fluorescence characters [10].

\section{Evaluation of in vitro antioxidant activity of methanolic extract of} Lindernia ruellioides (Colsm.) Pennell.

Determination of total phenolic content

The total phenolic content was determined using Folin-Ciocalteu reagent. To $1 \mathrm{ml}$ of extract, $5 \mathrm{ml}$ of Folin-Ciocalteu reagent were added. After $3 \mathrm{~min}, 4 \mathrm{ml}$ of $0.7 \mathrm{M} \mathrm{Na}_{2} \mathrm{CO}_{2}$ solution were added. In the same manner, different concentrations of standard gallic acid solutions (20, $40,60,80$, and $100 \mu \mathrm{g} / \mathrm{ml}$ ) were prepared. Both the sample (extract) and the standard (gallic acid) were kept at room temperature for 1 h. The absorbance of the solution was taken against the blank at 550 nm using UV-Visible Spectrophotometer. The total phenol content was expressed in GAE (mg/g) of the extract [11,12].

\section{Determination of total flavonoids content}

One milliliter of the extract was taken and added $2 \mathrm{ml}$ of methanol. Keep for $5 \mathrm{~min}$, add $3 \mathrm{ml}$ of $5 \%$ sodium nitrite and $0.3 \mathrm{ml}$ of $10 \%$ aluminum chloride, keep for $6 \mathrm{~min}$. Add $2 \mathrm{ml}$ of $\mathrm{NaOH}(1 \mathrm{M})$ and make up the volume up to $10 \mathrm{ml}$ with methanol and keep for $1 \mathrm{~h}$. In the same manner, the concentration of standard quercetin $(20,40,60,80$, and $100 \mu \mathrm{g} / \mathrm{ml})$ was prepared. The absorbance of the solution was taken against blank at $510 \mathrm{~nm}$ using a UV-Visible spectrophotometer. The total flavonoids were expressed in QE (mg/g) of the extract $[13,14]$.

\section{Determination of DPPH $\quad(2,2-$ diphenyl-1-picrylhydrazyl $)$} Scavenging activity

The free-radical scavenging activity of the plant samples and ascorbic acid as a positive control was determined using the stable DPPH (2,2-diphenyl 1-picrylhydrazyl). Aliquots $(20-100 \mu \mathrm{g} / \mathrm{ml})$ of the test samples are prepared in the test tube, $3 \mathrm{ml}$ of each concentration of the test samples were taken and $0.5 \mathrm{ml}$ of freshly prepared DPPH in methanol were added. 
Incubate the test samples at $37^{\circ} \mathrm{C}$ for $30 \mathrm{~min}$. The absorbance was measured using a UV-Visible spectrophotometer at $517 \mathrm{~nm}$. Ascorbic acid is used as a standard. The DPPH scavenging radical was calculated using the following equation [15]

DPPH scavenged $(\%)=\{($ Ac $-\mathrm{At}) / \mathrm{Ac}\} \times 100$

\section{Determination of reducing power}

The reducing power of the methanolic extract was determined using ascorbic acid as the standard. One milliliter of extract and $1 \mathrm{ml}$ of standard with various concentrations $(20,40,60,80$, and $100 \mu \mathrm{g} / \mathrm{ml}$ ) were mixed with $2.5 \mathrm{ml}$ of $1 \%$ potassium ferricyanide. The mixture was then incubated at $50^{\circ} \mathrm{C}$ for $30 \mathrm{~min}$, after which $2.5 \mathrm{ml}$ of $10 \%$ trichloroacetic acid were added. Centrifugation was done at $3000 \mathrm{rpm}$ for $10 \mathrm{~min}$. Take the supernatant $(2.5 \mathrm{ml})$ which was formed after centrifuged was diluted with $2.5 \mathrm{ml}$ distilled water and $0.5 \mathrm{ml}$ of $0.1 \%$ ferric chloride and shake well. The absorbance was measured at $700 \mathrm{~nm}$ using a UV-Visible spectrophotometer. The higher absorbance of the reaction mixture indicated that reducing power is increased [16].

\section{Determination of Nitric oxide scavenging activity}

To $0.5 \mathrm{ml}$ of $10 \mathrm{Mm}$ sodium nitroprusside in phosphate-buffered saline ( $\mathrm{pH} 7.2), 0.1 \mathrm{ml}$ of different concentrations $(20-100 \mu \mathrm{g} / \mathrm{ml})$ of sample extract and standard of ascorbic acid were added. Incubate the mixture at $25^{\circ} \mathrm{C}$ for $180 \mathrm{~min}$. To this, add $1.5 \mathrm{ml}$ of freshly prepared Griess reagent. At $510 \mathrm{~nm}$, the absorbance was measured using a UV-Visible spectrophotometer. Control was prepared using phosphate buffer + sodium nitroprusside and Griess reagent [17].

Nitric oxide scavenged $(\%)=($ Ac - At $) / A c \times 100$.

\section{RESULTS}

The extractive yield of different solvent

Six hundred and forty-two grams of powdered leaves of Lindernia ruellioides (Colsm.) Pennell were successively extracted using petroleum ether, chloroform, and methanol. The concentrated extract was kept in the refrigerator for further activity use. The extractive yield is given in Table 1 .

\section{Preliminary phytochemical screening}

The result of the phytochemical study is shown in Table 2. Most of the plant's extracts contained a rich source of secondary metabolites. Methanolic extract of Lindernia ruellioides (Colsm.) Pennell shows the presence of amino acid, flavonoids, tannins, steroids, and triterpenoids.

\section{Proximate composition}

The powdered leaves of Lindernia ruellioides (Colsm.) Pennell was taken for proximate composition analysis. Moisture analysis is an

Table 1: Extractive yield of different solvent (mean \pm SEM)

\begin{tabular}{lll}
\hline S. No. & Extract & \% yield \\
\hline 1. & Petroleum ether & 1.45 \\
2. & Chloroform & 2.804 \\
3. & Methanol & 7.025 \\
\hline
\end{tabular}

Table 2: Result of phytochemicals screening of methanolic extract of Lindernia ruellioides (Colsm.) Pennell

\begin{tabular}{lll}
\hline S. No. & Phytoconstituents & Results \\
\hline 1. & Alkaloids & - \\
2. & Amino acid & + \\
3. & Carbohydrates & - \\
4. & Flavonoids & + \\
5. & Tannins & + \\
6. & Steroids & + \\
7. & Triterpenoids & + \\
\hline$(-)$ Indicates absent $(+)$ Indicates present
\end{tabular}

important and widely employed determination which is widely used during formulation, processing, and testing of food products. The amount of moisture content in food products is a measure of yield and quantity and is of economic importance. The chemical, physical, and microbial stability of foods are affected by the properties of water. Less moisture or removal or dehydration of moisture is a technique used for improving food storage stability [18]. The result shows the moisture content $12.7 \%$ which has less content of moisture and can improve food storage stability. If the ash content is found to be in high amount, it is considered that the plant is rich in minerals which can provide a substantial amount of minerals to our diet. The plant contains rich sources of proteins that could be beneficial and helpful in the functioning of antibodies preventing infection [19]. The proximate composition of Lindernia ruellioides (Colsm.) Pennell is shown in Table 3.

\section{Fluorescence analysis}

The chemical constituents present in plant material exhibited various fluorescence which is an important phenomenon. If the substances themselves are not fluorescent, they may be often converted into fluorescent derivatives by reagents; hence, some crude drugs are often assessed qualitatively in this way and it is an important parameter of pharmacognostic evaluation [20].

The result for fluorescent studies of the powdered material using different chemical reagents was studied and given in Table 4.

\section{Evaluation of in vitro antioxidant activity}

Determination of total phenol content

Phenolic compounds are the most abundant secondary metabolites in plants and play an importantrole in pigmentation, growth, and reproduction of the plant, together with resistance to pathogens and predators. This is largely due to their phytoalexin properties and potent astringency. They have been shown to provide anti-allergic, anti-inflammatory, antioxidant, hepatoprotective, antiviral, and anticarcinogenic activities [21]. The

Table 3: Proximate composition of Lindernia ruellioides (Colsm.) Pennell (n=3)

\begin{tabular}{lll}
\hline S. No. & Proximate composition & Amount \\
\hline 1. & Moisture content $(\%)$ & 12.7 \\
2. & Ash content $(\%)$ & 0.43 \\
\hline
\end{tabular}

Table 4: Fluorescence analysis of Lindernia ruellioides (Colsm.) Pennell using different reagent $(n=3)$

\begin{tabular}{|c|c|c|c|c|}
\hline \multirow[t]{2}{*}{ S. No } & \multirow[t]{2}{*}{ Reaction mixture } & \multirow[t]{2}{*}{ Visible light } & \multicolumn{2}{|c|}{ UV Fluorescence } \\
\hline & & & $254 \mathrm{~nm}$ & $366 \mathrm{~nm}$ \\
\hline 1. & Powder as such & Pale green & brown & Pale green \\
\hline 2. & $\begin{array}{l}\text { Powder }+1 \mathrm{~N} \mathrm{NaOH} \\
\text { in water }\end{array}$ & Dark brown & $\begin{array}{l}\text { Dark } \\
\text { brown }\end{array}$ & $\begin{array}{l}\text { Yellowish- } \\
\text { green }\end{array}$ \\
\hline 3. & $\begin{array}{l}\text { Powder + glacial } \\
\text { acetic acid }\end{array}$ & Yellowish green & $\begin{array}{l}\text { Dark } \\
\text { brown }\end{array}$ & Brown \\
\hline 4. & $\begin{array}{l}\text { Powder }+1 \% \\
\text { picric acid in water }\end{array}$ & Yellow & $\begin{array}{l}\text { Light } \\
\text { yellow }\end{array}$ & Yellow \\
\hline 5. & $\begin{array}{l}\text { Powder }+5 \% \text { ferric } \\
\text { chloride }\end{array}$ & Dark brown & $\begin{array}{l}\text { Dark } \\
\text { brown }\end{array}$ & Brown \\
\hline 6. & Powder + conc. & Reddish-brown & brown & Light \\
\hline 7. & $\begin{array}{l}\mathrm{H}_{2} \mathrm{SO}_{4} \\
\text { Powder + conc. } \\
\mathrm{HNO}_{3}\end{array}$ & Reddish-brown & orange & $\begin{array}{l}\text { green } \\
\text { Light } \\
\text { brown }\end{array}$ \\
\hline 8. & $\begin{array}{l}\text { Powder + conc. } \\
\text { HCL }\end{array}$ & Pale brown & $\begin{array}{l}\text { Pale } \\
\text { brown }\end{array}$ & Brown \\
\hline 9. & $\begin{array}{l}\text { Powder + } \\
\text { methanol }\end{array}$ & Light green & $\begin{array}{l}\text { Pale } \\
\text { green }\end{array}$ & Orange \\
\hline 10. & $\begin{array}{l}\text { Powder + } \\
\text { Ammonia }\end{array}$ & Dark brown & brown & $\begin{array}{l}\text { Light } \\
\text { yellow }\end{array}$ \\
\hline 11. & Powder + water & Pale green & $\begin{array}{l}\text { Pale } \\
\text { green }\end{array}$ & Green \\
\hline
\end{tabular}


antioxidant activity of phenolics is considered mainly because of the presence of their redox properties, which allows them to act as reducing agents, hydrogen donors, and singlet oxygen quenchers [22]. Phenolic content was measured using the Folin-Ciocalteu reagent in the extract. The results were derived from a calibration curve $(y=0.0153 \mathrm{x}-0.1107, \mathrm{R} 2=$ $0.999)$ of gallic acid $(0-250 \mu \mathrm{g} / \mathrm{mL})$ and expressed in gallic acid equivalents (GAE) per gram dry extract weight. The result of the total phenolic content of the extract was found to be $152 \mathrm{mg} \mathrm{GAE} / \mathrm{g}$, as shown in Fig. 1 .

\section{Determination of total flavonoids content}

Flavonoids are secondary metabolites with antioxidant activity, the potency of which depends on the number and position of free $\mathrm{OH}$ groups [23]. Flavonoids such as flavones, flavanols, and condensed tannins are considered as plant secondary metabolites which are antioxidant activity and it depends on the presence of free $\mathrm{OH}$ groups, especially 3-OH. Plant flavonoids have antioxidant activity in vitro and also act as antioxidants in vivo [24]. Flavonoid contents in plant extracts were determined using aluminum chloride in a calorimetric method. The results were derived from the calibration curve $(y=0.0015+0.0334, \mathrm{R} 2=0.9904)$ of quercetin $(0-100 \mu \mathrm{g} / \mathrm{mL})$ and expressed in quercetin equivalents (QE) per gram dry extract weight. The result of the total flavonoids content of the extract was found to be $80 \mathrm{mg} \mathrm{QE} / \mathrm{g}$, as shown in Fig. 2 .

Determination of 2,2-diphenyl -1-picrylhydrazyl (DPPH) radical scavenging activity

Free radicals are highly reactive compounds that can produce oxidative stress on the body causing diseases such as atherosclerosis or cancer.

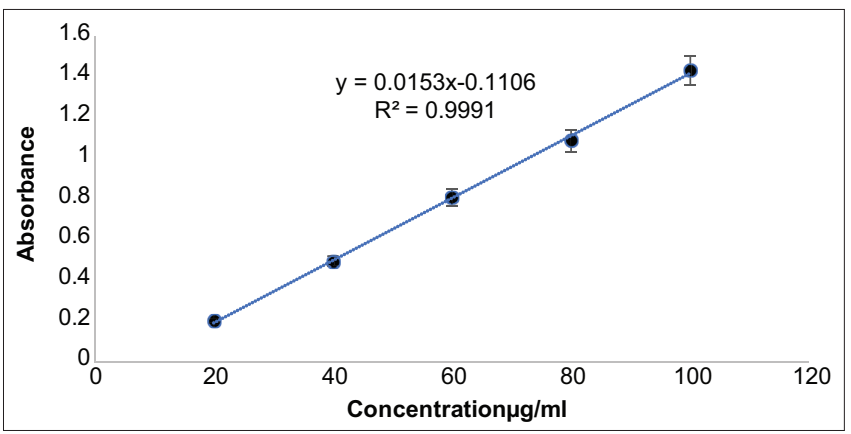

Fig. 1: Standard calibration curve of total phenolic content

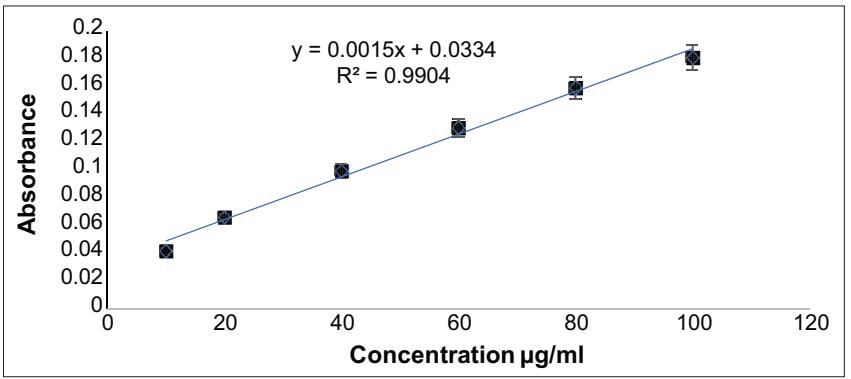

Fig. 2: Standard calibration curve for total flavonoid content

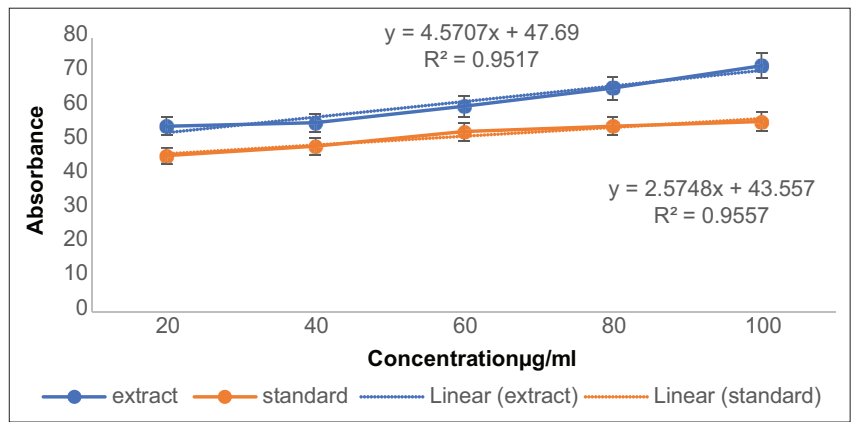

Fig. 3: Calibration curve for DPPH Scavenging Activity
To achieve atomic stability, free radicals are oxidized surrounding molecules to obtain a pair of electrons. This oxidative damage can be counteracted with primary or secondary antioxidants [25]. DPPH is a free radical which is stable at room temperature and this method is often employed to determine the antioxidant activity of many plant extracts. The concentration in $\mathrm{g} / \mathrm{ml}$ of the sample to scavenge $50 \%$ of the DPPH radical is called IC50 and lower IC50 values indicate the higher antiradical activity [26]. The \% inhibition of extract and the standard is shown in Table 7. The IC50 of Lindernia ruellioides (Colsm.) Pennell was found to be $9.50 \mu \mathrm{g} / \mathrm{ml}$, while the IC50 of the standard was found to be $50.59 \mu \mathrm{g} / \mathrm{ml}$, as shown in Fig. 3. Thus, the results indicate that the methanolic extract of Lindernia ruellioides (Colsm.) Pennell showed significantly higher antioxidants than the standard ascorbic acid.

\section{Determination of reducing power}

Reducing power is associated with an antioxidant activity which serves as a significant role of the antioxidant activity. Compounds that are reducing power are electron donors and can able to reduce the oxidized intermediates of lipid peroxidation processes and can act as primary and secondary antioxidants. In this essay, the yellow color of the test solution changes to various shades green and blue depending on the

Table 5: Mean absorbance value of total phenolic content (mean \pm SEM)

\begin{tabular}{ll}
\hline Concentration & Standard Gallic acid (MEAN \pm SEM) \\
\hline 20 & $0.2033 \pm 0.0020$ \\
40 & $0.496 \pm 0.0005$ \\
60 & $0.809 \pm 0.0005$ \\
80 & $1.09 \pm 0.0036$ \\
100 & $1.435 \pm 0.0008$ \\
\hline
\end{tabular}

Table 6: Mean absorbance value of total flavonoids content (mean \pm SEM)

\begin{tabular}{ll}
\hline Concentration & Standard (Quercetin) (MEAN \pm SEM) \\
\hline 10 & $0.041 \pm 0.0012$ \\
20 & $0.066 \pm 0.0015$ \\
40 & $0.099 \pm 0.0006$ \\
60 & $0.130 \pm 0.0008$ \\
80 & $0.159 \pm 0.0010$ \\
100 & $0.181 \pm 0.00057$ \\
\hline
\end{tabular}

Table 7: \% inhibition of DPPH of the methanolic extract of Lindernia ruellioides (Colsm.) Pennell and ascorbic acid. Data analyzed by one-way ANOVA followed by Dunnett's: Compared all versus control test for $n=3$

\begin{tabular}{lll}
\hline Concentration & $\begin{array}{l}\text { \% Inhibition of Ascorbic } \\
\text { acid (MEAN } \pm \text { SEM) }\end{array}$ & $\begin{array}{l}\text { \% Inhibition of Extract } \\
\text { (MEAN } \pm \text { SEM) }\end{array}$ \\
\hline 20 & $45.623 \pm 0.5451^{* *}$ & $54.248 \pm 0.326^{* *}$ \\
40 & $48.366 \pm 0.6232^{* *}$ & $55.215 \pm 0.1429^{* *}$ \\
60 & $52.614 \pm 0.3268^{* *}$ & $60.130 \pm 0.326^{* *}$ \\
80 & $54.248 \pm 0.3268^{* *}$ & $65.418 \pm 0.326^{* *}$ \\
100 & $55.556 \pm 0.3268^{* *}$ & $72.000 \pm 0.5660^{* *}$ \\
\hline
\end{tabular}

" $\mathrm{p}<0.05, " \mathrm{p}<0.01, " \mathrm{p}<0.001$, are considered to be very significant and extremely significant

Table 8: Rate of reducing the power of methanolic leaf extract of Lindernia ruellioides (Colsm.) Pennell and ascorbic acid

\begin{tabular}{lll}
\hline Concentration & $\begin{array}{l}\text { Standard ascorbic acid } \\
\text { (MEAN } \pm \text { SEM) }\end{array}$ & $\begin{array}{l}\text { Extract } \\
\text { (MEAN } \pm \text { SEM) }\end{array}$ \\
\hline 20 & $0.129 \pm 0.0011$ & $0.1236 \pm 0.0006$ \\
40 & $0.187 \pm 0.0003$ & $0.152 \pm 0.0005$ \\
60 & $0.302 \pm 0.0005$ & $0.215 \pm 0.0003$ \\
80 & $0.431 \pm 0.0005$ & $0.246 \pm 0.0003$ \\
100 & $0.597 \pm 0.0005$ & $0.299 \pm 0.0006$ \\
\hline
\end{tabular}




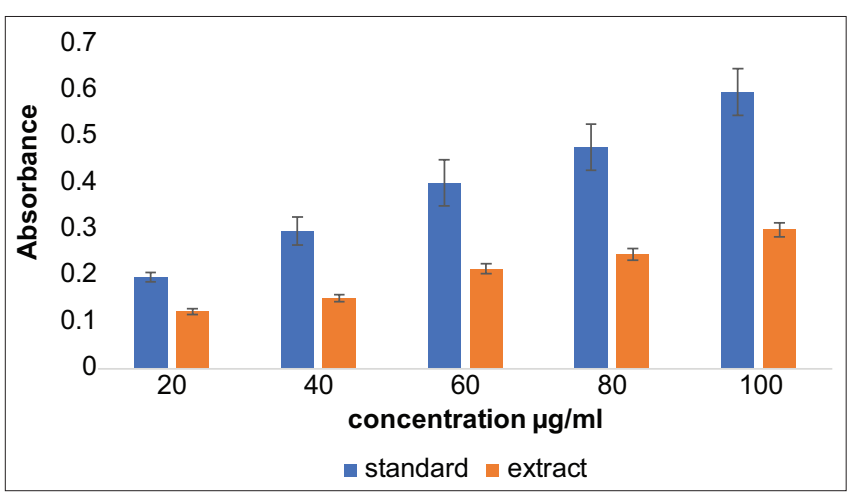

Fig. 4: Calibration curve of reducing power activity

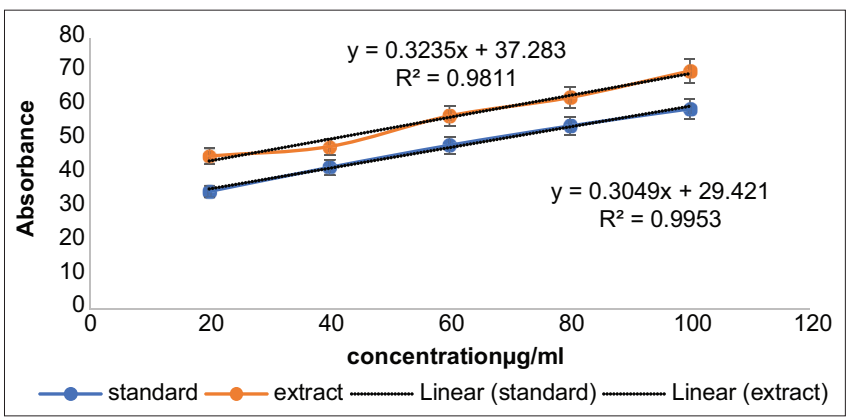

Fig. 5: Calibration curve of nitric oxide scavenging activity

reducing power of each compound. The presence of reducers causes the conversions of the ferricyanide complex in this method to the ferrous form [27]. The reducing power assay is often used to evaluate the ability of an antioxidant to donate an electron. In this assay, the presence of antioxidants in the sample resulted in a reduction of the ferric cyanide complex $(\mathrm{Fe} 3+)$ to the ferrous cyanide form $(\mathrm{Fe} 2+)$. Higher the absorbance of the reaction mixture, higher would be the reducing power, suggesting that the sample was able to terminate the radical chain reaction [28]. The reducing power of the standard ascorbic acid was significantly higher compared to the sample Lindernia ruellioides (Colsm.) Pennell, as shown in Fig. 4.

\section{DETERMINATION OF NITRIC OXIDE SCAVENGING ACTIVITY}

Nitric oxide (NO) is a free radical that is derived from the interaction of NO with oxygen or reactive oxygen species. Nitric oxide is a free radical because of its unpaired electron and plays an important reactivity with certain types of proteins and other free radicals such as superoxide. Low concentrations of $\mathrm{NO}$ are sufficient in most cases to affect the physiological functions of the radical. The plants exhibited antioxidant activity by competing with oxygen to scavenge for the nitrite radical at physiological $\mathrm{pH}$ in an aqueous environment. An increase in the concentration of the extract increases the antioxidant activity. Nitric oxide scavenging activity can be estimated using a Griess illosvoy reaction. The compound sodium nitroprusside gets decompose in aqueous solution at physiological $\mathrm{pH}$ (7.2) producing NO [29]. The \% inhibition of extract and standard is given in Table 9. From the result, the IC50 of the methanolic extract of Lindernia ruellioides (Colsm.) Pennell was found to be $39.31 \mu \mathrm{g} / \mathrm{ml}$, while the standard of IC50 was found to be $67.49 \mu \mathrm{g} / \mathrm{ml}$, as shown in Fig.5.

\section{DISCUSSION}

The study suggests that the plant extract contains phytochemical constituents that are capable of donating hydrogen to a free radical to scavenge the potential damage. Presents of flavonoids derivatives show that the plant may have a wide range of antibacterial, antiviral, antiinflammatory, anticancer, and anti-allergic activities. So comparable with the findings in the literature for other extracts of plant products, our result suggested that phenolic and flavonoids may be the major contributors for
Table 9: \% Inhibition of nitric acid of the methanolic leaf extract of Lindernia ruellioides (Colsm.) Pennell and Gallic acid. Data analyzed by one-way ANOVA followed by Dunnett's: Compared all versus control test for $n=3$

\begin{tabular}{lll}
\hline Concentration & $\begin{array}{l}\text { \% Inhibition of Ascorbic } \\
\text { acid (MEAN } \pm \text { SEM) }\end{array}$ & $\begin{array}{l}\text { \% Inhibition of extract } \\
\text { (MEAN } \pm \text { SEM) }\end{array}$ \\
\hline $\mathbf{2 0}$ & $34.827 \pm 0.1867^{* *}$ & $45.284 \pm 0.093^{* *}$ \\
$\mathbf{4 0}$ & $41.923 \pm 0.093^{* * *}$ & $48.085 \pm 0.093^{* * *}$ \\
$\mathbf{6 0}$ & $48.459 \pm 0.038^{* *}$ & $57.142 \pm 0.161^{* *}$ \\
$\mathbf{8 0}$ & $54.155 \pm 0.093^{* *}$ & $62.558 \pm 0.093^{* *}$ \\
$\mathbf{1 0 0}$ & $59.197 \pm 0.093^{* *}$ & $70.401 \pm 0.093^{* *}$ \\
\hline
\end{tabular}

${ }^{*} \mathrm{p}<0.05,{ }^{* *} \mathrm{p}<0.01,{ }^{* * *} \mathrm{p}<0.001$, are considered to be very significant and extremely significant.

the anti-oxidant activity as the $\mathrm{IC}_{50}$ of the plant extract and the contents of phenolics or flavonoids exhibited significant correlation. From the result of moisture content, the crude drug shows less percentage, which can be concluded that the growth of bacteria, yeast, or fungi has a chance of minimum growth during storage. The result of total ash indicates less presence of impurities such as silicate, carbonate, and oxalate in the crude drug. Furthermore, the total ash of a crude drug reflects the purity of crude and the prepared drug. DPPH scavenging activity determined that methanolic extract of leaves of Lindernia ruellioides (Colsm.) Pennell plant showed better anti-oxidant potential by the DPPH method when compared to standard ascorbic acid and $\mathrm{IC}_{50}$ value was found to be $9.50 \mu \mathrm{g} / \mathrm{ml}$ and $50.59 \mu \mathrm{g} / \mathrm{ml}$ for ascorbic acid and methanolic extract, respectively. Hence, we can say this plant has significant antioxidant activity. Reducing power of standard was significantly higher when compared to the plant extract, which shows the antioxidant present in the sample cause the reduction of $\mathrm{fe}^{3+}$ to $\mathrm{fe}^{2+}$ and thus proving its reducing power. From the result of nitric oxide scavenging activity, the plant shows greater inhibition than the standard which may be due to the anti-oxidant principles in the extract, which compete with oxygen to react with the nitric oxide thereby inhibiting the generation of nitrite. Our findings suggest that the plant has the property to counteract the effect of nitric oxide formation due to the presence of tannins and flavonoids.

\section{CONCLUSION}

The extraction of the crude drug of Lindernia ruellioides (Colsm.) Pennell was done successively by the Soxhlet method using petroleum ether, chloroform, and methanolic.

The preliminary phytochemical screening of the methanolic extract of leaves of Lindernia ruellioides (Colsm.) Pennell was performed and it was found to be the presence of amino acids, tannins, flavonoids, steroids, and triterpenoids. From the phytochemicals, results obtained it can be said that it is useful in the detection of bioactive principles which may lead to drug discovery and development.

From the result of the estimation of proximate composition, the high amount of ash content is rich in minerals and could provide a substantial amount of mineral elements to our diet.

The methanolic extract of Lindernia ruellioides (Colsm.) Pennell shows a significant anti-oxidant activity which may be due to the presence of phenol and flavonoids in plants. The findings of the present study showed that this plant has a potential source of natural anti-oxidant.

\section{ACKNOWLEDGMENT}

The authors would like to thank Dr. Chawmgthanliana, Director of RIPANS and Dr. H. Lalhlenmawia, Head of Department of Pharmacy, for providing facilities to conduct this research work.

\section{CONFLICTS OF INTEREST}

The author's declared that they have no conflicts of interest in publishing this research article. 


\section{AUTHOR'S CONTRIBUTIONS}

The corresponding author performed a collection of plants, extraction, experimental work, and wrote the manuscript and analyzed the data. The coauthor helped in evaluating the final manuscript. All the authors have read and agreed on the final approval of the manuscript.

\section{AUTHOR'S FUNDING}

This work is completely self-funded.

\section{REFERENCES}

1. Wei JC, Wang PC, Zhou XL, Tang K, Luo Q, Xu Q, et al. The caffeoyl phenylethanoid glycosides from Lindernia ruellioides and their antiHBV effects. J Asian Natl Prod Res 2017;20:757-62.

2. Zakhuma P. The Book of Mizoram Plants M. Sawmliana.; 2003;pp 93.

3. Moualek I, Aiche GI, Guechaoui NM, Lahcene S, Houali K. Antioxidant and anti-inflammatory activities of Arbutus unedo aqueous extract. Asian Pac J Trop Biomed 2016;6:1-8.

4. Ranjith D. Fluorescence analysis and extractive values of herbal formulations used for wound healing activity in animals. J Med plants Stud 2018;6:189-92.

5. Kokate CK. Pharmacognosy. Pune; 2010. p. 15.

6. Ahmad T, Sing SB, Pandey S. Phytochemical screening and physicochemical parameters of crude drugs a brief review. Int J Pharma Res Rev 2013;2:53-60.

7. Das AK, Nongmaithem R. Phytochemical study of selected medicinal plants used by the maring tribe of Chandel district, Manipur, India. J Pharmacogn Phytochem 2019;8:2155-60

8. Chaudhuri K, Hasan SK, Barai AC, Das S, Seal T, Bag BG. Nutraceutical evaluation of Rhynchotechum ellipticum, a potent wild edible plant consumed by the tribal of North-Eastern region in India and green synthesis of gold nanoparticles using its leaf extract. J Pharm Phyto 2018;7:1434-42.

9. Tapan S, Kausik C, Basundhara P. Nutraceutical and antioxidant properties of Cucumis hardwickii Royle. A potent wild edible fruit collected from Uttarakhand, India. J Pharm Phyto 2017;6:1837-47.

10. Pandey MK, Singh GN, Sharma RK, Lata S. Standerdization of yakrit plihantak churna: An ayurvedic polyherbal formulation. IJPSR 2011;3:171-6.

11. Renuka K, Devi VR, Subramanian SP. Phytochemical screening and evaluation of in vitro antioxidant potential of immature palmyra palm (borassusfla belliferlinn.) fruits. Int J Pharm Pharm Sci 2018;10:77-83.

12. Stankovic MS. Total phenolic content, flavonoid concentration and antioxidant activity of Marrubium peregrinumL. extracts. Kragujevac J Sci 2011;33:63-72

13. Usha B, Pushpalatha KC. In vitro antioxidant activity and phytochemical screening of leaf extracts of grewiaheterotricha mast. Int J Curr Pharm
Res 2016;8:68-72.

14. Malsawmtluangi C, Thanzami K, Lalhlenmawia H, Selvan V, Palanisamy S, Kandasamy R, et al. Physicochemical characteristics and antioxidant activity of Prunus cerasoides D. Don gum exudates. Int J Bio Macro 2014;69:192-9.

15. Nwakaego NL, Chibuike OK, Chukwugekwu EM, Marylyn AC, Ngozi EI, Chukwunonye ER. In vitro antioxidant and free radical scavenging potential of methanolic extracts of uvariachamae leaves and root. Int J Pharm Pharm Sci 2019;11:67-71.

16. Dumrongphuttidecha T, Thungmungmee S, Khobjai W, Wisidsri N, Techaeoi S. Antioxidant and free radical scavenging activity of hibiscus acetosella leaves extracts. Int J Appl Pharm 2019;11:86-9.

17. Satter MM, Khan MM, Jabin SA, Abedin N, Islam MF, Shaha B. Nutritional quality and safety aspects of wild vegetables consume in Bangladesh. Asian Pac J Trop Biomed 2016;6:125-31.

18. Park YW, Bell LN. Nutr Food Sci 2014.

19. Pourmorad F, Hosseinimehr SJ, Shahabimajd N. Antioxidant activity, phenol and flavonoid contents of some selected Iranian medicinal plants. Afr J Biotechnol 2011;5:1142-45

20. Kasthuri OR, Ramesh B. Physicochemical and fluorescence analysis of leaves of Alternanthera brasiliana (L). Kuntze and Alternanthera bettzickiana (Regel) Voss. Int J Pharm Sci 2018;11:66-71.

21. Noreen H, Semmar N, Farman M, McCullagh JS. Measurement of total phenolic content and antioxidant activity of aerial parts of medicinal plants Corono pusdidymus. Asian Pac J Trop Med 2017;11:792-801.

22. Chandra S, Khan S, Avula B, Lata H, Yang MH, ElSohly MA, et al. Assessment of total phenolic and flavonoid content, antioxidant properties, and yield of aeroponically and conventionally grown leafy vegetables and fruit crops. A comparative study. Evid Based Complement Alternat Med 2014;2014:253875.

23. Aryal S, Baniya MK, Danekhu K, Kunwar P, Koirala RG. Total phenolic content, flavonoid content and antioxidant potential of wild vegetables from Western Nepal. J Plants 2019;8:96.

24. Baba SA, Malik SA. Determination of total phenolic and flavonoid content, antimicrobial and antioxidant activity of a root extract of Arisaema jacquemontii Blume. J Taibah Univ Sci 2015;9:449-54.

25. Anggraini T, Wilma S, Syukri D, Azima F. Total phenolic, anthocyanin, catechins, DPPH radical scavenging activity, and toxicity of Lepisanthe salata (Blume) Leenh. Int J Food Sci 2019;2019:7.

26. Abdille MH, Singh RP, Jayaprakasha GK, Jena BS. Antioxidant activity of the extracts from Dillenia indica fruits. J Food Chem 2004;90:891-6.

27. Jayanthi P, Lalitha P. Reducing power of the solvent extracts of Eichhornia crassipes (Mart.) solms. Int J Pharm Pharm Sci 2011;3:3.

28. Anandjiwala S, Bagul MS, Parabia M, Rajani M. Evaluation of free radical scavenging activity of an ayurvedic formulation, Panchvalkala. Indian J Pharm Sci 2008;70:31-5

29. Boora F, Chirisa E, Mukanganyama S. Evaluation of nitrite radical scavenging properties of selected zimbabwean plant extracts and their phytoconstituents. J Food Proc 2014;2014:7. 